\title{
MB21D2 Gene
}

National Cancer Institute

\section{Source}

National Cancer Institute. MB21D2 Gene. NCI Thesaurus. Code C132170.

This gene plays a role in protein-protein interactions. 